\title{
Applied AVSWAT 2000 for Assessment of Pollutant Load in Brantas River Basin, Indonesia
}

\author{
M. Sholichin ${ }^{1, a}$ Faridah Othman ${ }^{2, b}$, S.M.Shirazi ${ }^{2, c}$, Shatirah Akib ${ }^{2, d}$, Donny \\ Harisuseno $0^{1, e}$ and Dian Sising ih $^{1, f}$ \\ ${ }^{1}$ Water Resources Department, Faculty of Engineering, University of Brawijaya, East Java, \\ Indonesia; \\ ${ }^{2}$ Department of Civil Engineering, Faculty of Engineering, University of Malaya, Kuala Lumpur, \\ Malaysia \\ a'mohsholichin@yahoo.com, 'baridahothman@edu.um.my, 'shirazi@edu.um.my \\ dshatirahakib@edu.um.my, 'donnyhari@yahoo.com, ${ }^{\text {'s }}$ singgih@ub.ac.id
}

Keywords: Pollutant load, AVSWAT2000, Brantas River.

Abstract:This paper presented the results of assessment pollutant load such as nutrient and phosphorus on Brantas River basin Indonesia. A Soil and Water Assessment Tool (SWAT) was choose to applied in this study due to successful for simulate the effect land used management from large watershed in many countries. Stream flow and sediment yield were calibrated for the 19912003 period and validated for the 2004-2006 period. The resulting statistical goodness-of-fit was evaluated with the Nash-Sutcliffe coefficient NS $=0.38$ and $\mathrm{R}^{2}$ of the one-to-one line for monthly stream flow was 0.725 . Results showed that annual average nutrient loads such as organic $\mathrm{N}$, organic P, nitrate, sediment P increased in trend from 1991 to 2006. Simulated results showed that average annual nutrient load was $60.88 \mathrm{~kg} \mathrm{~N} / \mathrm{ha} / \mathrm{yr}$ for organic N, $11.64 \mathrm{~kg} \mathrm{~N} / \mathrm{ha} / \mathrm{yr}$ for Nitrate, 0.08 $\mathrm{kg} \mathrm{P} / \mathrm{ha} / \mathrm{yr}$ for organic $\mathrm{P}$ and $0.25 \mathrm{~kg} \mathrm{P} / \mathrm{ha} / \mathrm{yr}$ for soluble $\mathrm{P}$, respectively. The most dominant type of land use contributing to increased nutrient load in rivers was the rice field. The water quality of Brantas River did not meet class II in term of nutrient parameters based on local water quality standard.

\section{Introduction}

Similar to most of the developing countries in South East Asia, Indonesia have most of the contemporary water quality problems of the developed nations such as pollution, eutrophication, toxicity development, ecosystem dysfunction, acidification to follow with air pollution now aggravated through long standing forest fires. In past 10 years, the conditions of river in many places in Indonesia have been decreasing of water quality status. About 64 from 470 of watersheds have been determinate of critical status. For 64 watersheds, they are 12 watersheds in Sumatra, 26 watersheds in Java, 10 watersheds in Kalimantan, 10 watersheds in Sulawesi, 4 watersheds in Bali and 4 watersheds in Papua. Base on 26 watersheds in Java that categories critical condition is Brantas river basin included [1]. More than 18 million people are living in the Brantas catchments area and depend on its resources. It contains most of East Java's water reservoir capacity and produces about ten per cent of the nation's rice crop. The Brantas River with a total length of 320 $\mathrm{km}$ and a catchments area of $11,050 \mathrm{~km} 2$ is the second largest river of Java. It functions as the most important source of water supply in the East Java Province especially for Surabaya big City [2]. The condition of rivers is rapidly deteriorating and has caused serious problems in availability of safe water for human consumption [3],[4]. The major problem in Brantas River is to improve the water quality of the river system to meet the demand from different sectors and to improve the capacity of water supply for domestic, industry, agriculture, energy, tourism and other uses. 
Materials and methods

Description of river system of study area

The Brantas River is the second largest river on the Java Island. Its length is $320 \mathrm{~km}$ and catchment area is about $11,800 \mathrm{~km}^{2}$ lying on East Java province, which covers around $9 \%$ of the total area of the Java Island. The river basin geographically extends between $110^{\circ} 30^{\prime}$ and $112^{\circ} 55^{\prime}$ of east longitude and between $7^{\circ} 01^{\prime}$ and $8^{\circ} 15^{\prime}$ of south latitude [5]. The river system and its profile of the Brantas River are shown in Figure 1.

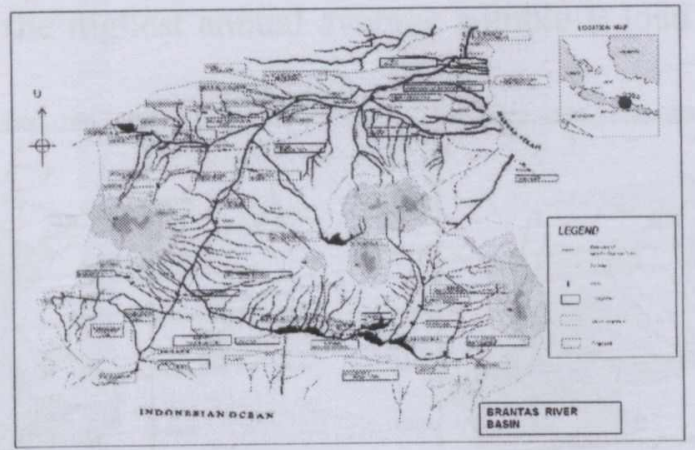

Figure 1. Map of the Brantas River Basin, Indonesia

\section{Watershed Modeling (AVSWAT model)}

SWAT - the Soil and Water Assessment Tool- was developed by the USDA Agricultural Research Service (ARS) [6] to predict the impact of land management practices on water, sediment and amount of chemicals originating from agriculture, in large complex river basins with varying soils, land use and management conditions over a long period of time. It is a partly physically-based and partly distributed, continuous model with a daily calculation time step. As such, the model is not designed to simulate detailed, single-event flood routing. SWAT incorporates features of several ARS models and is a direct outgrowth of the SWRRB model (Simulator for Water Resources in Rural Basins) [7], [8]. Specific models that contributed significantly to the development of SWAT were CREAMS (Chemicals, Runoff, and Erosion from Agricultural Management Systems) [9] and GLEAMS (Groundwater Loading Effects on Agricultural (Erosion-Productivity Management Systems) [10]. We used the AVSWAT2000 version of the model, where the simulator is integrated in a GIS by an ArcView pre-processor [11]. It uses a grid digital elevation model (DEM), polygon/grid coverage of soils and land use, and point coverage of weather stations as basic input to the model.

\section{Results and discussion}

Model calibration and validation are necessary and critical step in any model application. Its purpose to assure that the calibration model properly assesses all the variables and conditions which can affect model results, and demonstrate the ability to predict field observations for periods separate from the calibration effort. Calibration of the SWAT model has been done which tree steps, hydrology, sediment and nutrient. Model was calibrated from 1991 to 2003 were accurate when compared with the measured data $\mathrm{R}^{2}=0,725$ (Figure 2.3) and resulting of statistical goodness-of-fit was evaluated with the Nash-Sutcliffe coefficient NS $=0,38$ (Figure. 2)
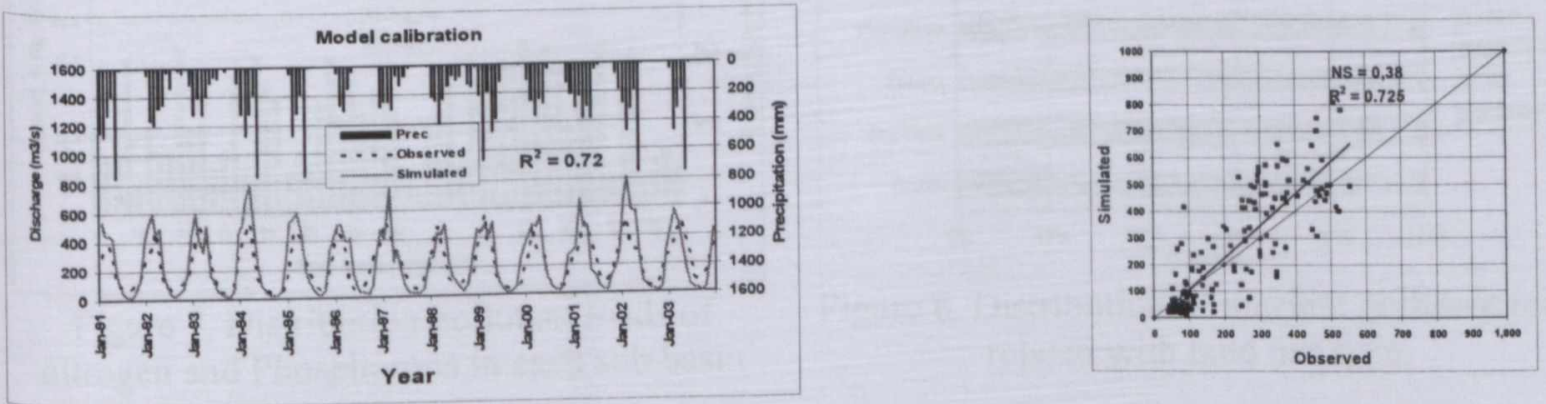

Figure 2. Observed and predicted monthly of stream flow and Observed Vs predicted graph 
The result shows that annual precipitation is highest in the sub basin around the mountains. The maximum value of annual precipitation was around 2,494 to $3,260 \mathrm{~mm} / \mathrm{year}$. The highest runoff is dominated in the lower reach with maximum value around 827.61 to $1,341.80 \mathrm{~mm}$. The organic $\mathrm{N}$ load was $60.88 \mathrm{~kg} \mathrm{~N} / \mathrm{ha} / \mathrm{yr}$ in middle reach which dominate by rice field was highest value of nitrogen transported (Figure 3). It was understand, because in this area, the local farmer usually fertilizer very intensive and over doses. The average maximum nitrogen load has occurred in downstream area which value $11.64 \mathrm{~kg} \mathrm{P} / \mathrm{ha} / \mathrm{yr}$ (Figure 4) and annual average organic P load was $0.8 \mathrm{~kg} \mathrm{P} / \mathrm{ha} / \mathrm{yr}$. Meanwhile, the highest annual average soluble P load was $0.25 \mathrm{~kg} \mathrm{p} / \mathrm{ha} /$ year (Fig. 6).

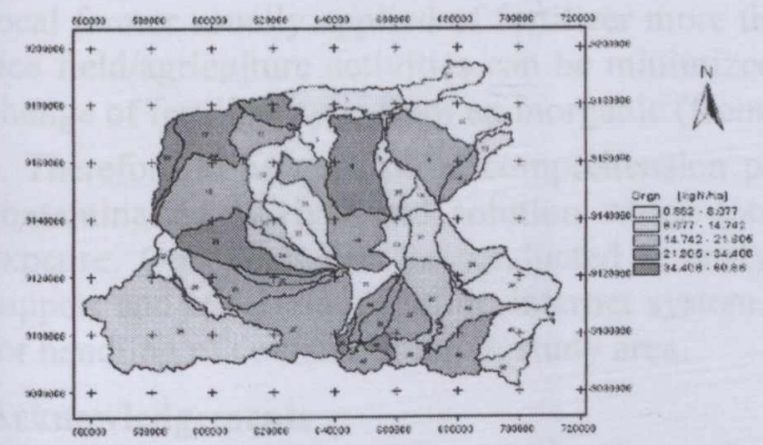

Figure. 3 Annual Organic N Load (kg- N/ha/yr)

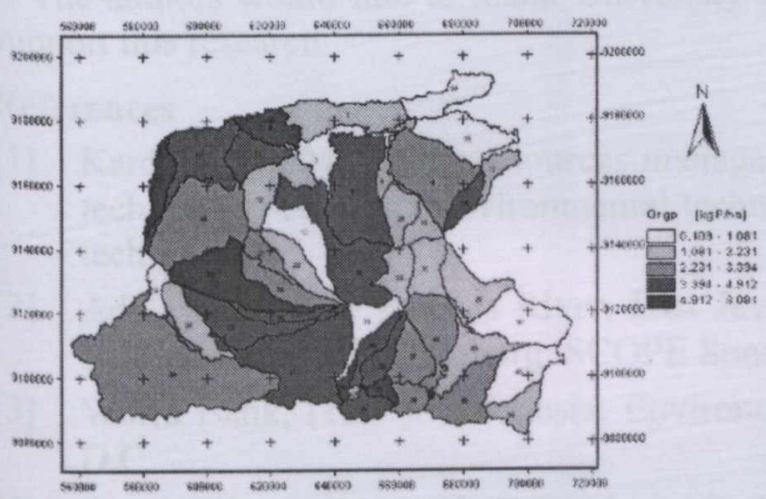

Figure. 5 Annual organic P load (kg P/ha/yr)

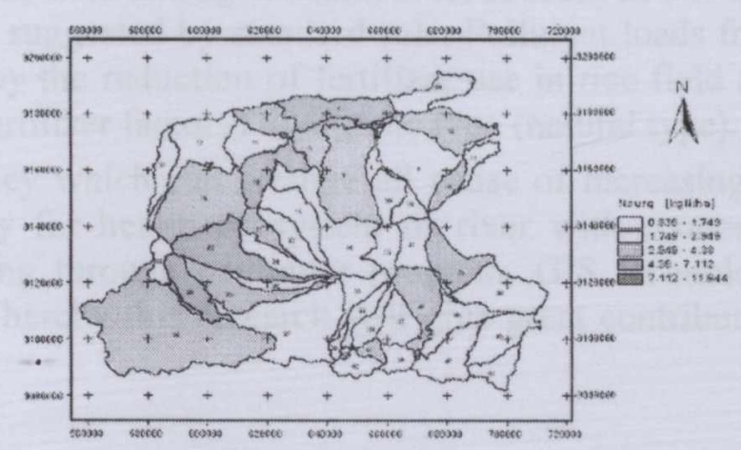

Figure. 4. Annual Nitrogen in surface runoff $(\mathrm{kg} \mathrm{N} / \mathrm{ha} / \mathrm{yr})$

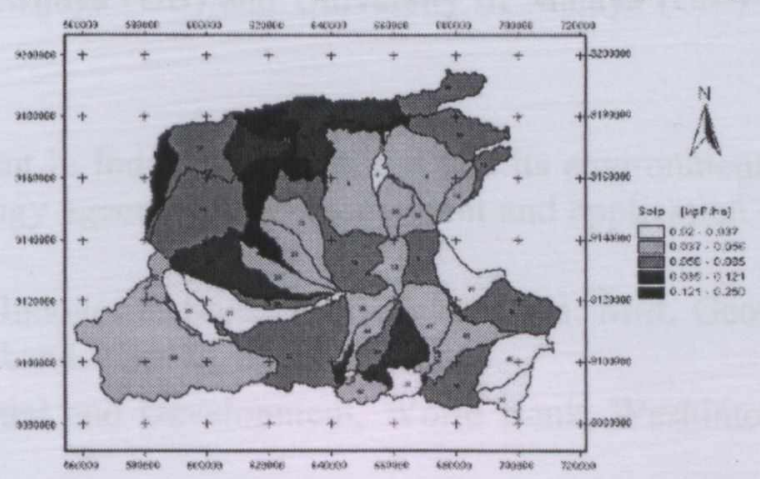

Figure 6. Annual soluble P load (kg P/ha/yr)

The distribution of pollutant load such as nitrogen and phosphorous load in each sub basin can be seen in Figure. 7. The majority of sources pollutant load from sub basin number 37 to 45 . Distribution of nitrogen and phosphorous load pollutant that related with land use in each sub basin can be seen in Figure 8. The land use of rice field was highest contribution load of nitrogen in study area about $82 \%$. The minimum contribution of nutrient load pollutant was forest area.

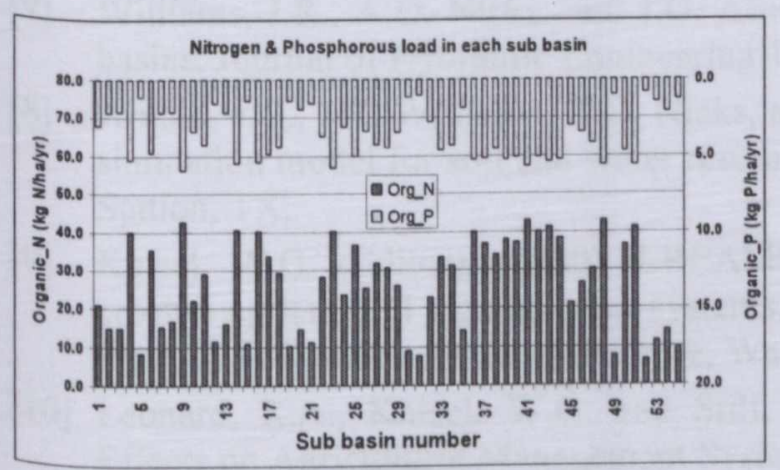

Figure 7. Distribution pollutant loads of nitrogen and Phosphorous in each sub basin

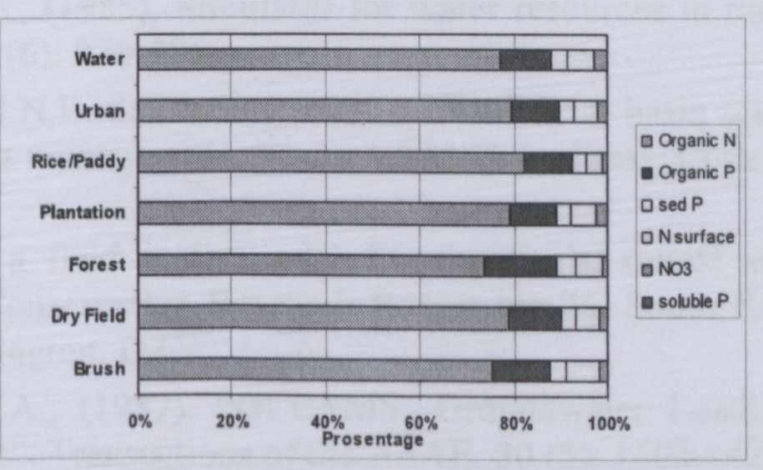

Figure 8. Distribution of nutrient pollutant load related with land use type. 


\section{Conclusions}

Most Pollutant load such as the nitrogen and phosphorus load in river water come from soil erosion, soil type, and land management. Nutrient load (nitrogen $\&$ phosphorous) resulting from non-point sources pollutant are of concern in the Brantas river basin. Brantas River has experienced large alga bloom in the past. Base on analysis and results of SWAT simulation, non-point source pollutant from rice field and urban area higher that pollutant load from point source on the upstream reach and middle stream reach.

Nitrogen and phosphorous load was highest in rice field and agricultural area, because in this area local farmer usually applied of fertilizer more that suggested by standard rule. Pollutant loads from rice field/agriculture activities can be minimized by the reduction of fertilizer use in rice field and change of fertilizer type from an inorganic (from fertilizer factory) to organic type (natural type).

Therefore to be need more comprehension policy which can arrange all cause of increasing of contamination in river and solution which totally for health ecosystem of river with economic expense. One other can be conducted is analyzing through computer program, GIS technology support and telecommunication internet system. Thereby this research will give great contribution for handling of contamination in study area.

\section{Acknowledgements}

The authors would like to thank University Brawijaya (UB) and University of Malaya (UM) to support this research

\section{References}

[1] Kardono, (2004), water resources management in Indonesia; condition and its environmental technology, center of environmental technology agency for the assessment and application of technology at.

[2] Adi, (1999). The Brantas River, East Java, Indonesia: Some Preliminary Data. Mitt. Geol.Paläont. Inst. Univ.Hamburg. SCOPE Sonderband, Heft 82. S. 173-183.

[3] World Bank, (1994). Indonesia: Environmental and Development, World Bank, Washinton, D.C.

[4] Crooks, R., (1991). Kali Surabaya Pollution Control: Review of water quality trends", Institutional arrangements.

[5] Ramu, Kikkeri, (1999). River Basin Management Corporation, an Indonesian Approach. June 1999, Third River Basin Management Workshop, World Bank, Washington D.C.

[6] Arnold, J.G., Srinivasan, R., Muttiah, R.S., Williams, J.R., (1998). Large area hydrologic modelling and assessment part I: Model development. J. Am. Water Resource. Assoc., 34 (1), 73-89.

[7] Williams, J.R., A.D. Nicks, and J.G. Arnold., (1985). Simulator for water resources in rural basins. Journal of Hydraulic Engineering 111(6): 970-986.

[8] Arnold, J.G., J.R. Williams, A.D. Nicks, and N.B. Sammons, (1990). SWRRB: A basin scale simulation model for soil and water resources management. Texas A\&M Univ. Press, College Station, TX.

[9] Knisel, W.G. (Editor), (1980). CREAMS: a field scale model for chemicals, runoff and erosion agricultural management systems. Conservation Research Report No 26, South East Area, U.S. Department of Agriculture, Washington, D.C.

[10] Leonard, R.A., Knisel, W.G. and Still, D.A., (1987). "GLEAMS: Groundwater Loading Effects on Agricultural Management Systems". Transactions of the ASAE, 30 (5): 1403-1428.

[11] DiLuzio, M., Srinivasan, R., and Arnold, J.G., (2003). A GIS-hydrological model system for the watershed assessment of agricultural nonpoint and point sources of pollution. Transactions in GIS, 2004, 8(1): 113-136. 
Advanced Building Materials

doi:10.4028/www.scientific.net/AMR.250-253

Applied AVSWAT 2000 for Assessment of Pollutant Load in Brantas River Basin, Indonesia

doi:10.4028/www.scientific.net/AMR.250-253.3945 